\title{
Spatial characterization of noise levels at the Federal University of Agriculture, Abeokuta, Nigeria
}

\author{
Oyedepo J. A. ${ }^{1, *}$, Omoniyi D. M. ${ }^{2}$, Oluyege D. E. ${ }^{1}$ and Babajide E. I. ${ }^{1}$ \\ ${ }^{1}$ Environmental Resources and Conservation Research Programme, IFSERAR, Federal University of \\ Agriculture, Abeokuta, Ogun State, Nigeria \\ ${ }^{2}$ Department of Environmental Management and Toxicology, College of Environmental Resources \\ Management, Federal University of Agriculture Abeokuta, Ogun State, Nigeria \\ Corresponding Author: *johnoyedepo@yahoo.com
}

https://doi.org/10.36263/nijest.2020.02.0218

\begin{abstract}
The study investigated the spatial variability in the distribution of noise pollution in Federal University of Agriculture, Abeokuta. Measurements of noise were taken from 10 locations on campus namely; the academic environment including the University library and college lecture auditoria, the residential areas comprising the Student hostels and Vice-chancellor's lodge as well as other populated areas like the car park and student union building. The noise measurement was done in the morning and evenings of Mondays, Wednesdays and Saturdays over a period of 3 weeks in July 2019. The noise measurement was done with the aid of Smart Sensor Digital Sound Level meter (Model: AR824). The sampling points were geo-located using a hand-held receiver for Global Positioning Systems (GPS). Questionnaires were administered to members of the University community (staff and students) to determine their respective perception of campus noise on academic activities. Data (noise and survey) were subjected to statistical analysis. Spatial analysis of the noise levels includes surface interpolation (Krigging) to determine the spatial pattern of noise across the campus, particularly, the most tranquil and most chaotic locations. The results show noise pollution levels reaching $74.3(\mathrm{db})$ and $73.0(\mathrm{db})$ during weekdays at some locations on campus. The noise emission level at some locations within the University exceeded the World Health Organization and Federal Ministry of Environment of Nigeria's permissible level of $55 \mathrm{db}$ for residential areas. Generally, it was observed that the ambient noise from heavy duty generating with the student chattering put noise level above $35(\mathrm{db})$ to $55(\mathrm{db})$ recommended for educational institutions. It can be inferred from statistical analyses and spatial interpolations of recorded noise levels, that noise levels of many areas in FUNAAB exceed the recommended $40 \mathrm{db}$ required for an institution of higher learning. The study however finds that staff and students have adjusted to the noise on campus. Lecturers have resorted to the use of public address systems in large classes while students go to serene locations for better assimilation when studying. The study recommends reduction of point-source noises such as replacing the diesel generators with solar power. Signage should be displayed at sensitive areas such as library to reduce unnecessary noise.
\end{abstract}

Keywords: Campus noise, Cognitive disturbance, Spatial variability, Tranquility maps, GIS, FUNAAB

\subsection{Introduction}

Learning environments require minimum noise interference for effective teaching and assimilation (Kruger and Zannin, 2004; Dockrell and Shield, 2012; Karamikh and Firoozabadi, 2012; Lewinski, 2015; Feng and Li, 2016). Students taught in the absence of noise interference according to Olaosebikan, (2020) recorded significantly higher assimilation than their peers who were taught in the presence of noise. Other authors such as: Pheng et al., (2006), Ana et al., (2009), Golmohammadi et al., (2010), Woolner and Hall, (2010), Debnath et al., (2012), Alsubaie, (2014) as well as Gilavand and Jamshidnezhad, (2016) have also reported that exposure to environmental noise decrease cognitive performance of students. Hygge et al., (2002) and Elmenhorst et al., (2010) reported that noise introduces difficulties in communication, Simões-Zenari et al., (2009) pointed out that noise 
impairs attention and can frustrate effective performance. Thakur (2006) also established that a strong correlation exists between noise and annoyance. Ikenberrgy, (1974) analyzed some effects of noise pollution on school students and found that students find it difficult to hear the teacher during lectures or actively participate in classroom discussions. Klatte et al., (2013) showed that students who learn in tranquil environments perform better than those who do under chaotic conditions. Debnath et al., (2012) stated that noise pollution produces multi-problems to the teaching-learning process and negatively affects the performance of both teachers and students.

Classrooms are primarily the venue for long and arduous process of individual and collective education (Zannin et al., 2013). It is in the classroom that contact is established between teachers and students and between individual students and their peers. It is in the classroom that knowledge is transferred through oral communication. The quality of classroom education is therefore dependent on ambient acoustic quality; which is often characterized by reverberation time, speech transmission index, sound insulation, and noise levels inside and outside (Zannin and Zwirtes, 2009). Where there are high noise levels around the classroom, oral communication are impaired; the students become bored and are unable to assimilate. Noise creates premature fatigue in students causing negative effects on their cognitive skills (Hagen et al., 2002).

Schools are expected to ensure the best possible conditions for the student's physical and intellectual development, including control of excess environmental noise (Ana et al., 2009). For the University environment, the critical effects of noise apply mainly to speech interference, disturbance of information extraction (e.g. comprehension and reading acquisition), message communication and annoyance (Lundquist et al., 2000; Bakasa, 2011; Annick et al., 2012; Nassiri et al., 2013). To be able to hear and understand spoken messages in classrooms, the background sound pressure level should not exceed 35 dB LAeq during teaching sessions (Kamal et al., 2010; Augustyńska et al., 2010). Speech in relaxed conversation is $100 \%$ intelligible and can be understood fairly well where the background noise levels does not exceed the range of 35 to $45 \mathrm{dBA}$, but, with background sound pressure level of $65 \mathrm{dBA}$ speech can only be understood with more vocal efforts (WHO, 2000). For outdoor environment (e.g., playground), the sound pressure level of the noise from external sources should not exceed $55 \mathrm{~dB}$ LAeq (Berglund et al., 2000), the same value given for outdoor residential areas in day-time.

Meanwhile, noises are not completely avoidable; they have become part of human daily lives (MacKenzie and Galbrun, 2007) according to Tobías et al., (2015), a day with absence of noise in any community is abnormal. Noises only become deleterious when they are chaotic and impinge negatively on human health and activities. In recent times, noise pollution has been of increasing concern worldwide, particularly due to the associated negative issues in the urban centers (Buxton et al., 2017; Gupta et al., 2018; Owen, 2019; Piličić et al., 2020; Nazir et al., 2020). Noise is associated with vagaries of mental and physical effects described noises as harmful human activities Some of the health-related problems that have been linked to extensive exposure to noise include hearing loss, insomnia and psychological deteriorations (Zannin et al., 2002). These and other psychosomatic impacts makes noise one of the most harmful and pervasive environmental pollutants today (Essandoh and Armah, 2011; Basner et al., 2014).

In the scope of cognitive performance, auditory stress and associated physiological costs, noise may affect the learning behaviors of students, and very noisy places are therefore not suitable for teaching structures (Spreng, 2000; WHO, 2009). Non-auditory effects are associated with effects on work performance, such as reduction of productivity and misunderstanding what is heard; psychological effects such as disorders, sleeplessness, irritability and stress; physiological effects, such as increased blood pressure, irregularity of heart rhythms and ulcers. Noise pollution can play havoc with the nervous system affecting the physical and psychological behavior of individuals (Stansfeld et al., 2000; Passchier, 2000; Marius et al., 2005; Aweda et al., 2010; Usikalu et al., 2016a). People differ in their sensitivity to noise, in that, what one perceives to be sound may be perceived as noise by another.

Quite a number of authors have embarked on studies on noise pollution in Nigeria in the last two decades. Some instances include Oyedepo and Saadu (2008a) and Oyedepo and Saadu (2010) which compared noise pollution levels in selected areas of Ilorin Metropolis; Oyedepo (2013a), which 
investigated the effective noise control measures and sustainable development in Nigeria; Digha and Tabe (2013) which assessed of noise pollution level in Trans-Amadi industrial lay-out in Port Harcourt. Baloye and Palamuleni (2015) also reported on a Comparative Land Use-Based analysis of noise pollution levels in selected urban centers of Nigeria while Emenike and Sampson (2017), documented noise levels and quality of livelihoods in residential neighbourhoods of Port Harcourt metropolis. Most of the studies on noise such as (Oyedepo et al., 2018; Oyedepo et al., 2019) have rather concentrated on urban centres as against the few that gave a cursory look at the schools and academic environments. Until very recently, noise level evaluations have also failed to introduce spatial techniques for graphical presentation of noise intensities. Where some studies have examined impacts of noise on student's performances in schools, they have failed to explore the spatial pattern of the problem; particularly with the aim of identifying areas that exceed the permissible limits and must be mediated. Ana et al., (2009) presented the result of an assessment of noise and its associated health Impacts at selected secondary schools in Ibadan while Otutu (2011) reported on the outcome of an investigation of environmental noise within campus of Delta state University, Abraka. The result of the two studies however did not provide basis for spatial decision support for deployment of mitigation measures since noise level mapping was omitted. The use of GIS has been de-emphasized in many noise level investigations; thus making deployment of mitigations difficult. Incidentally, one of the few studies on noise levels that considered the learning environment as well as introduced the aspect of mapping was Akintunde et al., (2020) which mapped the distribution of noise levels within University of Jos and determined the intensity of noise at various locations within the campus at different times and days of the week. The study however omitted the element of spatial decision support for noise intervention; although spatial presentation of average noise levels it was however limited as it did not consider spatio-temporal characteristics of noise in the campus.

The problem of environmental noise pollution in citadel of higher learning has to be properly characterized and tackled as it steadily grows in the campuses of developing countries. This paper brings to the fore, the status of noise pollution and its effects on teaching and learning process in the University while also setting the backdrop for further studies. The paper aims at assessing the level of noise pollution and its effect on teaching and learning processes within the campus area of Federal university of Agriculture, Abeokuta. This is achieved by assessing the noise pollution within the campus in different time and days; identifying various noise sources as well as exploring the variability distribution of noise through spatial tranquility mapping of the campus. The paper also determines the consequences of noise pollution on productivity of staff and student.

\subsection{Methodology}

\subsection{Study area}

The Federal University of Agriculture, Abeokuta, Nigeria (FUNAAB) which is situated between latitude $7.1475^{\circ} \mathrm{N}$ and longitude $3.3619^{\circ} \mathrm{E}$ covers a large area of land of about $371 \mathrm{~km}^{2}$ on an altitude of $379 \mathrm{~m}$ above sea level. The study area is a meeting point that accommodates all and sundry. The University operates a collegiate system and has 9 colleges with 41 departments. The campus is replete with various types of business activities including; food canteens, typesetting and photocopying, groceries and cybercafés. Others include transport. Most business centres run on small generating sets which together with the bigger power generators, vehicular noise and students' activities constitute sources of raucousness that characterizes a typical Nigerian University environment. The map in Figure 1 shows the University campus and the important structures and centres.

\subsection{Sampling design}

The geographical coordinates of the sampling positions were taken with the aid of a hand-held GPS receiver. Data collection was conducted at 10 different points which were selected using systematic sampling within the study area from where noise level measurement was done. Questionnaires were administered to staff and students that were randomly selected in the campus. For the opinion survey, a combination of stratified and random sampling was employed in getting the appropriate sample population to which the structured interview was administered. 


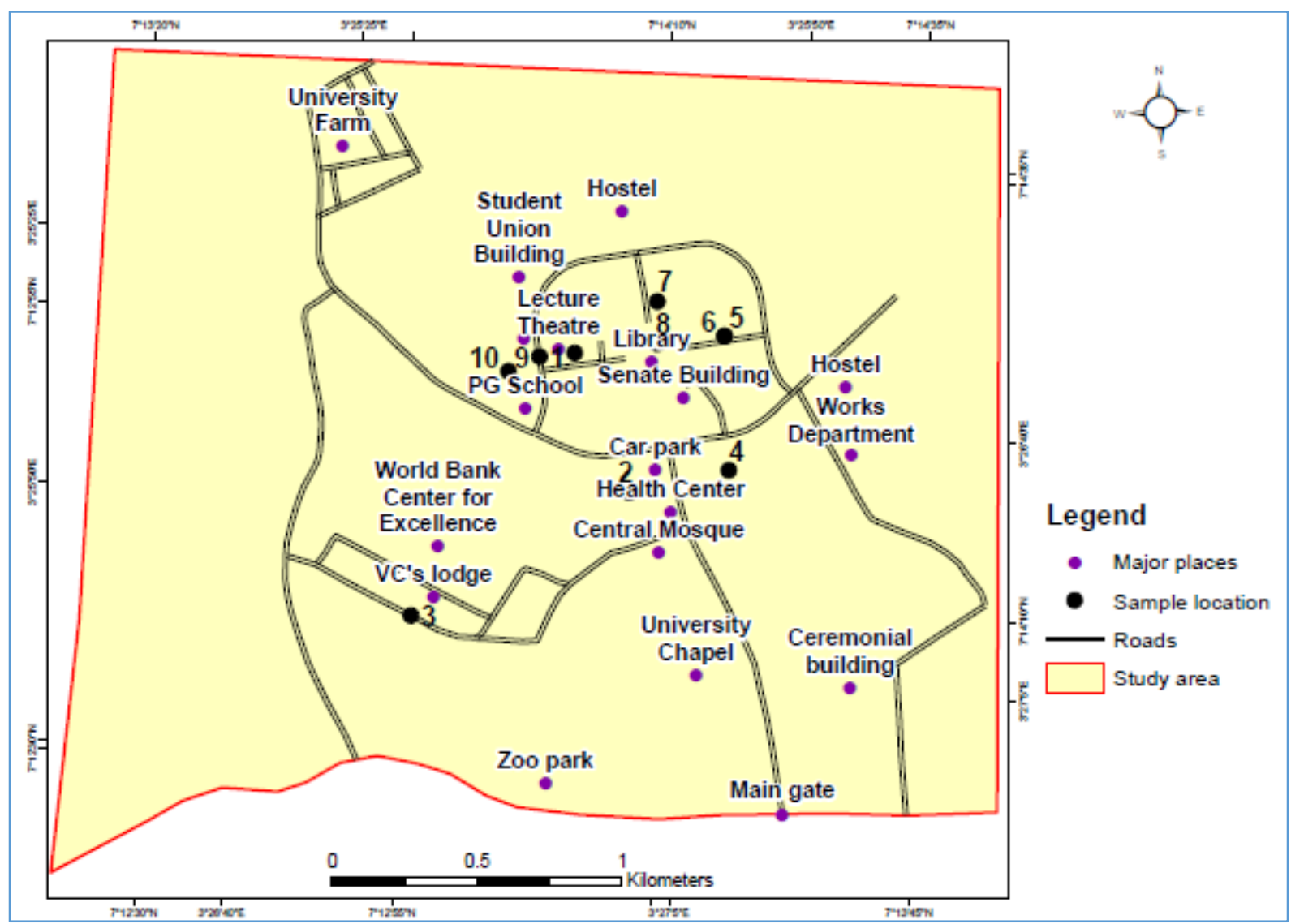

Figure 1: Map of the study area

\subsection{Materials}

The study deployed Smart Sensor Digital Sound Level meter (Model: AR824) with range of 30 130 decibels, handheld global Position System (GPS) receiver, ArcGIS (10.4), and statistical package for data acquisition and analysis as the cases are.

\subsection{Noise measurement}

The ambient noise measurement was carried out using a sound level meter, during the months of September to November, 2019. The noise level meter was set at the slow response mode with Aweighting (A-weighted decibels (dBA)). The measurement was conducted twice per day (Morning and Evening), three times in a week (Monday, Wednesday and Saturday) for 3 month within the period of; 9:00 a.m. to 11:00 a.m. and from 2.00 p.m. to 6:00 p.m.

The noise levels were compared with World Health Organization standard and Federal Ministry of Environment permissible limits as contained in Tables 1 and 2.

Table1: World Health Organization guideline for community noise

\begin{tabular}{|c|c|c|c|c|}
\hline $\mathrm{S} / \mathrm{N}$ & Environment & $\begin{array}{l}\text { Permissible Sound } \\
\text { Level } \mathrm{dB}(\mathrm{A})\end{array}$ & $\begin{array}{l}\text { Permissible Exposure } \\
\text { period (hours) }\end{array}$ & Critical Health Effect \\
\hline 1 & Outdoor living areas & $50-55$ & 16 & Annoyance \\
\hline 2 & Indoor dwellings & 35 & 16 & Speech intelligibility \\
\hline 3 & Bedrooms & 30 & 8 & Sleep disturbance \\
\hline 4 & School classrooms & 35 & During class & $\begin{array}{l}\text { Disturbance of } \\
\text { communication }\end{array}$ \\
\hline 5 & $\begin{array}{l}\text { Industrial, commercial and traffic } \\
\text { areas }\end{array}$ & 70 & 24 & Hearing impairment \\
\hline 6 & Music through earphones & 85 & 1 & Hearing impairment \\
\hline 7 & Ceremonies and entertainment & 100 & 4 & Hearing impairment \\
\hline
\end{tabular}


Table 2: Federal Ministry of Environment noise standards

\begin{tabular}{lll}
\hline S/N & Description of Land use types & Permissible Noise Level \\
\hline 1 & For parts and open spaces & $60 \mathrm{dBA}$ (Exterior limit) \\
2 & Residential area, Hotels, Schools, Libraries, Hospitals etc & $70 \mathrm{dBA}$ ( Exterior limit) \\
3 & Developed areas & $75 \mathrm{dBA}$ \\
4 & Residential areas, Hotels, Libraries & $55 \mathrm{dBA}$ (Interior limit) \\
\hline
\end{tabular}

\subsection{Geo-locating the sample locations}

A hand held GPS receiver was used to obtain the coordinates of 10 locations where the noise levels are being monitored in the campus. The noise levels in decibels were tabulated against the respective geographic coordinates (longitudes and latitudes) of the sampling position. The locations and their descriptions are presented in Table 3.

Table 3: Noise mapping locations in the campus

\begin{tabular}{|c|c|c|c|c|c|}
\hline & & & Lat $\left({ }^{\circ} \mathbf{N}\right)$ & Long ( $\left.{ }^{\circ} \mathrm{E}\right)$ & Description \\
\hline 1 & SUB & Student Union Building & 7.228639 & 3.435297 & Largely commercial area \\
\hline 2 & CARPARK & University commercial bus terminus & 7.227938 & 3.439896 & $\begin{array}{l}\text { Largely commercial area with } \\
\text { shops and shuttle cabs and } \\
\text { buses }\end{array}$ \\
\hline 3 & VCLOGDE & Vice-Chancellor's lodge, & 7.220165 & 3.439805 & $\begin{array}{l}\text { Residential area for the } \\
\text { University Chancellor, Pro- } \\
\text { chancellor, and the Vice- } \\
\text { chancellor }\end{array}$ \\
\hline 4 & COLMAS & College of Management Science & 7.230959 & 3.440843 & Academic environment \\
\hline 5 & JAO & $\begin{array}{l}\text { Julius Ameoba Okojie Lecture } \\
\text { Theatre }\end{array}$ & 7.23293 & 3.437166 & $\begin{array}{l}3 \text { of the largest lecture theatres } \\
\text { on campus are here }\end{array}$ \\
\hline 6 & LIBRARY & University Library & 7.232928 & 3.437169 & Academic environment \\
\hline 7 & YAT & Iyalode Tinubu Hostel & 7.231656 & 3.435197 & Student residential area \\
\hline 8 & COLERM & $\begin{array}{l}\text { College of Environmental Resources } \\
\text { Management }\end{array}$ & 7.230996 & 3.436323 & Academic environment \\
\hline 9 & MPB & Oba Lipede Multipurpose Building & 7.227639 & 3.434849 & Lecture theatre and laboratories \\
\hline 10 & YAKUB. & Mahmood Yakub lecture theatre & 7.226574 & 3.434764 & The largest lecture theatre \\
\hline
\end{tabular}

Measurements were consistently recorded at ten (10) different locations in the campus namely; and these locations were considered because of their importance and human population density.

\subsection{Spatial map production}

The coordinates of the 10 sample locations with their respective noise level readings were tabulated using Microsoft Excel. The table was imported into Arc map in ArcGIS 10.4 with which the location map was drawn. Spatial interpolations of the values were done using krigging to depict the variability distribution of the noise levels for each day and time. The spatial pattern and trend of the noise meter readings for all the days and time intervals were made easy to appreciate. The GIS further combined the interpolated layer together using raster calculator to generate a final result called risk assessment map, scaling the whole are from high to low risk.

\subsection{Survey instrument}

Semi-structured questionnaires were administered to collect data related to environmental, health and learning related issues, with a focus on noise and its sources located outdoors and indoors. This was designed based on previous research by Shendell et al. (2002) and recommendations of Basner et al. (2014). The questionnaire's validity to measure the desired parameters was determined by experts' judgments in the Federal University of Agriculture, Abeokuta. To test the questionnaire for its reliability, a pre-test was carried out and the questionnaire was tested for its internal consistency using Cronbach's alpha in SPSS v20.

\subsection{Statistical analysis}

The data was subjected to one-way analysis of variance (ANOVA). The mean was separated using DUNCAN Multiple Range Test (DMRT) at 95\% significant level using SPSS Version 23.

- To assess the noise pollution within the campus in different time and days descriptive statistics was conducted on the noise meter acquired data. 
- To evaluate the various sources of the noise pollution, the perception-based questionnaire data was assessed using percentage analysis.

- To produce a spatial map of noise distribution in the study area, surface interpolation was conducted in the form of Kriging using noise meter acquired field readings in conjunction with GPS acquired geospatial coordinates.

- To find out the consequences of noise pollution on productivity of staff and students, the perception based data acquired from respondents using the questionnaires was assessed using percentage analysis.

\subsection{Results and Discussion}

\subsection{Schools and noise level}

Table 4 shows the measurement of noise level on Monday morning and evenings for the three weeks. The mean measurement carried out show that JAO (71.9dB), YAKUB (61.9dB), COLMAS (62.5dB), COLERM (66.6dB), MP (59.9dB) and CARPARK (64.1dB) have level exceed the $(55 \mathrm{~dB})$ permissible noise level for non-industrial areas (XXCV, 2014). The VCLOGDE (47.1dB), YAT (51.8dB), LIBRARY (54.0dB) and SUB (55.0dB) were relatively lower and safe.

Table 4: Monday morning and evening noise measurement

\begin{tabular}{llllllll}
\hline S/N & Location & $\mathrm{Mm} 1$ & $\mathrm{Me} 1$ & $\mathrm{Mm} 2$ & $\mathrm{Me} 2$ & $\mathrm{Mm} 3$ & $\mathrm{Me} 3$ \\
\hline 1 & SUB & 57.8 & 64.1 & 55.7 & 67.7 & 54.3 & 67 \\
2 & CARPARK & 63.3 & 71.8 & 64.9 & 70.7 & 65.2 & 70.1 \\
3 & VCLODGE & 45.1 & 48.5 & 47.5 & 48 & 48.6 & 48.8 \\
4 & COLMAS & 65.7 & 66.1 & 60.2 & 64.6 & 61.7 & 65.5 \\
5 & JAO & 70.1 & 74.3 & 69.8 & 72.6 & 75.9 & 72.3 \\
6 & LIBRARY & 52.1 & 69.6 & 56.5 & 69.7 & 53.4 & 69.5 \\
7 & YAT & 50.1 & 53.2 & 52.1 & 54.3 & 53.2 & 60.7 \\
8 & COLERM & 67 & 66 & 66.7 & 63.1 & 66.1 & 66.4 \\
9 & MP & 60.7 & 63.9 & 58.3 & 63.5 & 60.8 & 64.7 \\
10 & SUB & 66.3 & 62.8 & 57.1 & 64 & 62.5 & 51.3 \\
\multicolumn{7}{l}{ (Mm } \\
afternoon/evening)
\end{tabular}

The result indicate that for all locations studied on all Monday mornings, JAO is the noisiest with average morning and evening noise levels of 71.9 and 73.1 decibels respectively. This puts JAO ahead of College of Environmental Resources Management (COLERM) and car park with average morning and evening noise levels of 66.6 and 65.4 decibels respectively. Next to COLERM is the Car park with average morning and evening noise of 64.5 and 70.9 decibels respectively. ViceChancellor's lodge with morning and evening noise levels of 47.1 and 48.4 decibels respectively is expectedly the most tranquil point on campus for Mondays. JAO's noise level is attributed to the students' population densities around the three lecture theatres in this location. This is in line with the findings of Oyedepo (2013b) that low density areas could have noise level range of $43 \mathrm{db}$ to $59 \mathrm{db}$ in comparison to highly populated and areas with high vehicular traffic.

The table is more explicit in map form. The graphical presentation of the result for Monday morning and late afternoon is as presented in Figures $2 \mathrm{a}$ and $2 \mathrm{~b}$. Interpolations of the noise values in the ten location gives a spatial dimension of the noise levels across the campus. The highest noise range is however around the same locations for both morning and evenings as shown above.

The map in Figure 2a above depicts relative noise levels in all areas. For instance, the Car park, religious centre, health centre and even the library are within the nosiest zone on Monday mornings. Car park only measured up with JAO in the evening when student congregate for transport to town, since the university only lodges $30 \%$ of student on campus. Other locations are not as noisy as JAO on Mondays; this implies that most of the noise emanate from students' side talks, discussions and other non-formal activities. The VC lodge is the most tranquil. 


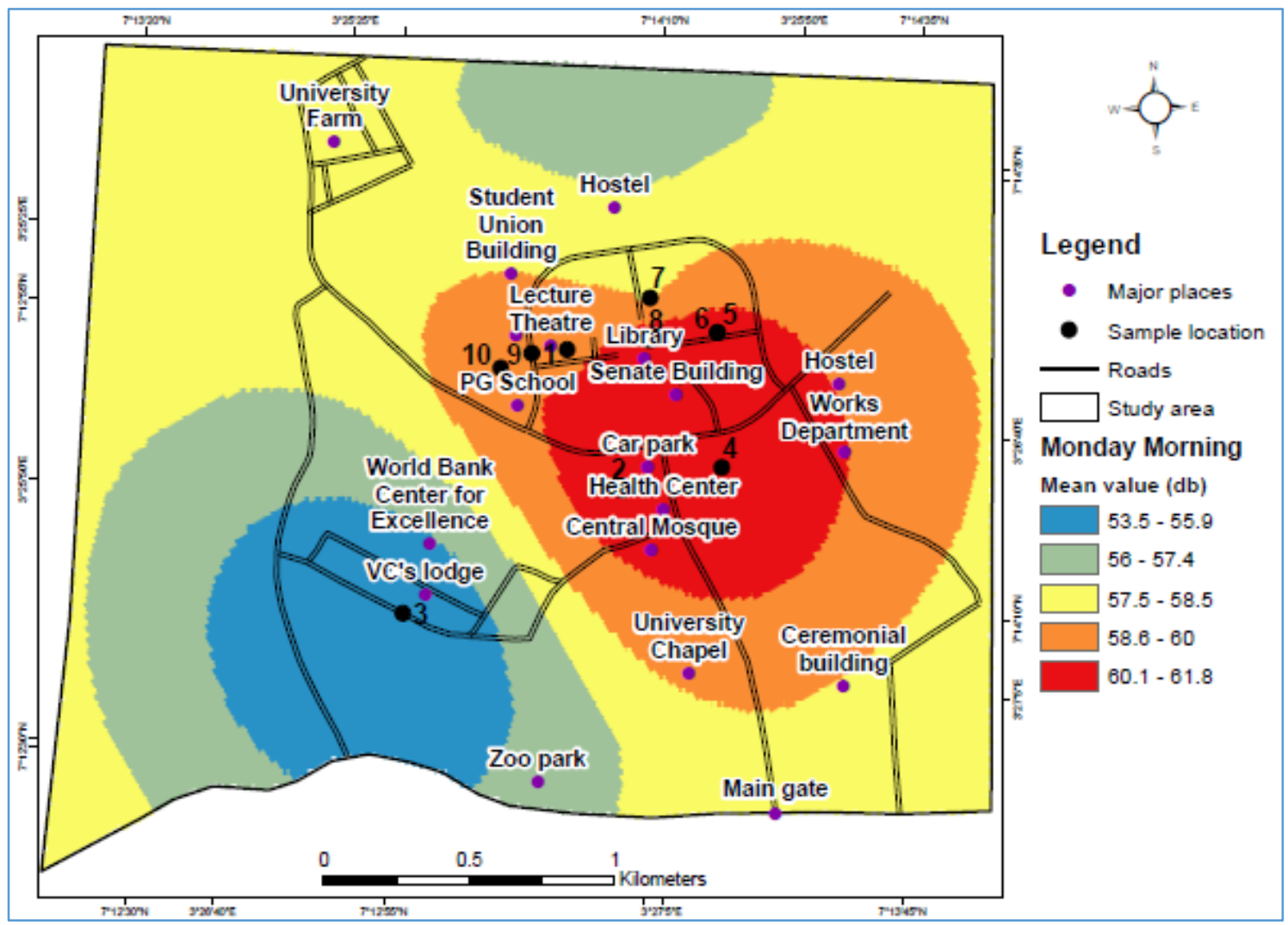

Figure 2a: Spatial variability of average noise level on Monday morning

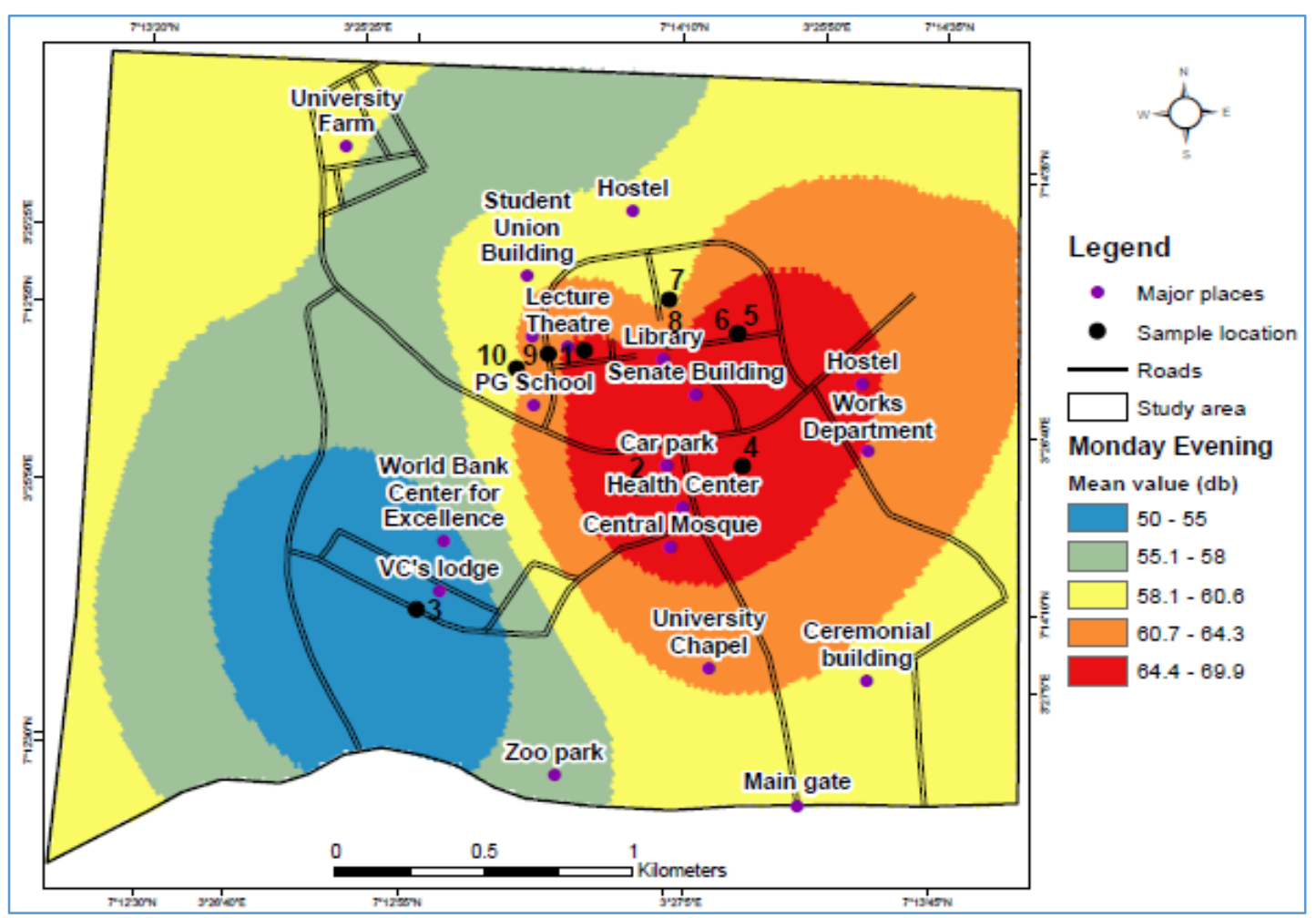

Figure 2b: Spatial variability of average noise level on Monday evening

The second map (Figure $2 \mathrm{~b}$ ) is the spatial distribution of average noise levels in the late afternoon of Mondays. The spatial pattern of the evening noise level looks similar to that of the morning except that in value, the minimum noise level is lover in the evening than in the morning and vice-versa for the maximum noise levels.

Again the Vice-chancellor's lodge is the most tranquil for the morning and evening being located away from student vicinity and surrounded by trees and vegetation. This finding aligns with Debnath 
et al. (2012) who stated that, trees and vegetation can absorb 4 to $6 \mathrm{~dB}$ noise intensity. Savale (2014) also corroborated this and suggested that green belt development can attenuate the sound levels. Akintunde et al. (2020) particularly reported on the attenuation properties of trees and vegetation in campus noise. The basic reason for the relatively high value of noise is largely due to the use of diesel generating set installed due to the epileptic supply of electricity to the University; as corroborated by Abulude et al. (2018) this, implies that once the public power supply is improved upon, the noise level will reduce automatically.

In Table 5, the noise levels at the 10 locations on Wednesday mornings and evenings are presented.

Table 5: Wednesday morning and evening noise measurement

\begin{tabular}{llllllll}
\hline S/N & Location & Wm1 & We1 & Wm2 & We2 & Wm3 & We3 \\
\hline 1 & SUB & 60.0 & 65.8 & 56.9 & 64.3 & 57.8 & 67.8 \\
2 & CARPARK & 64.1 & 72.1 & 61.8 & 71.1 & 62.7 & 75.1 \\
3 & VCLODGE & 43.4 & 44.5 & 46.7 & 47.7 & 47.6 & 48.0 \\
4 & COLMAS & 63.5 & 60.1 & 62.1 & 65.6 & 62.5 & 60.6 \\
5 & JAO & 73.2 & 77.9 & 74.1 & 71.1 & 73.7 & 69.8 \\
6 & LIBRARY & 65.7 & 55.4 & 66.1 & 65.1 & 54.1 & 70.0 \\
7 & YAT & 55.0 & 58.2 & 54.3 & 59.1 & 54.7 & 61.5 \\
8 & COLERM & 65.4 & 67.5 & 63.1 & 69.3 & 67.4 & 65.4 \\
9 & MP & 58.0 & 72.8 & 59.7 & 70.1 & 58.1 & 60.1 \\
10 & SUB & 65.9 & 64.8 & 65.7 & 65.1 & 66.6 & 59.8 \\
\hline
\end{tabular}

WM1-Wednesday morning week1, WE1 -Wednesday evening week1, WM2 - Wednesday morning week2, WE2 - Wednesday evening week2, WM3 -Wednesday morning week3, WE3-Wednesday evening week.

Again, the results indicate JAO as the noisiest with the highest mean noise level of 73.7 and 72.9 decibels for morning and evening respectively. Only the Vice-Chancellor's lodge with 45.9 and 46.7 decibels average noise levels for morning and evening was below the 55 decibel permissible level for residential areas. The graphical representation of the mean noise level for Wednesday morning and evening are shown in Figures $3 \mathrm{a}$ and $3 \mathrm{~b}$.

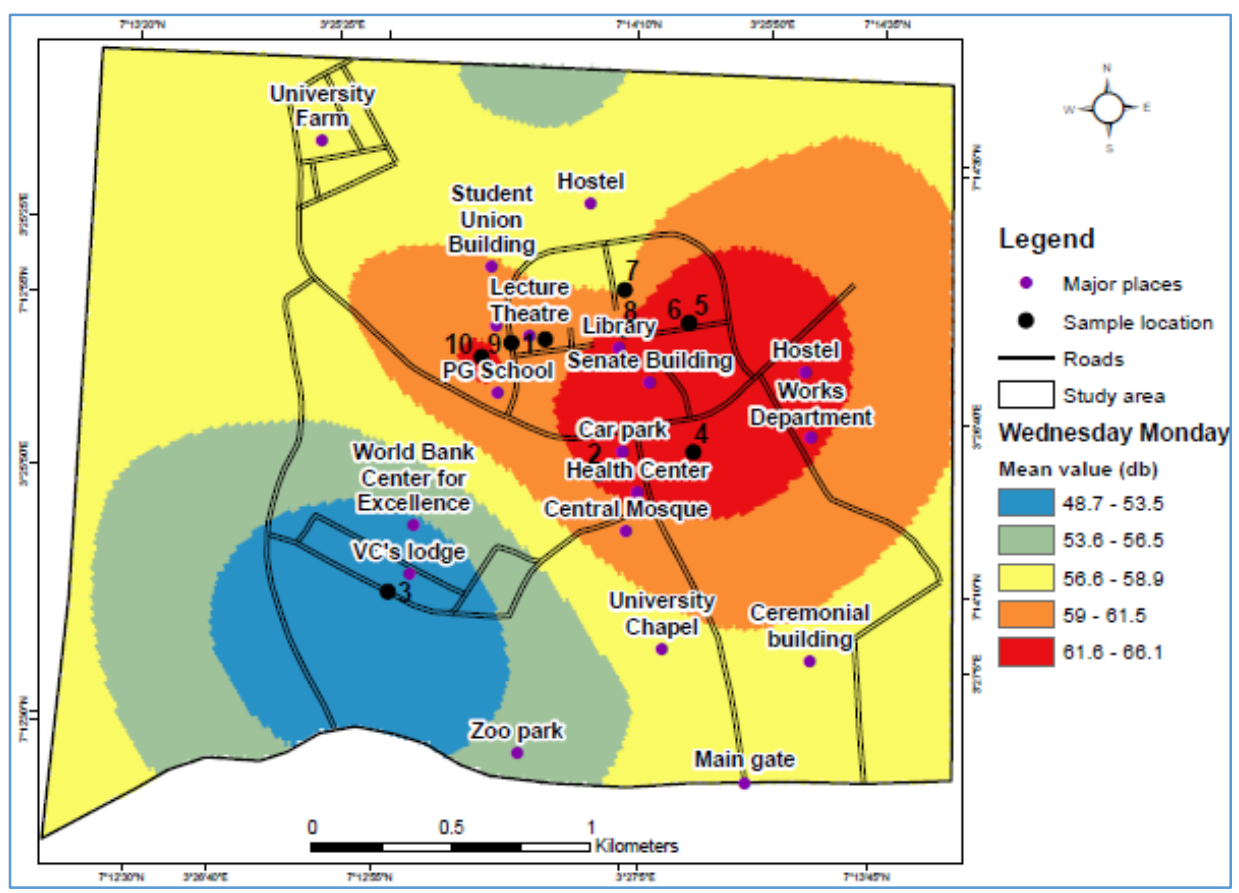

Figure 3a: Spatial variability of average noise level on Wednesday morning 


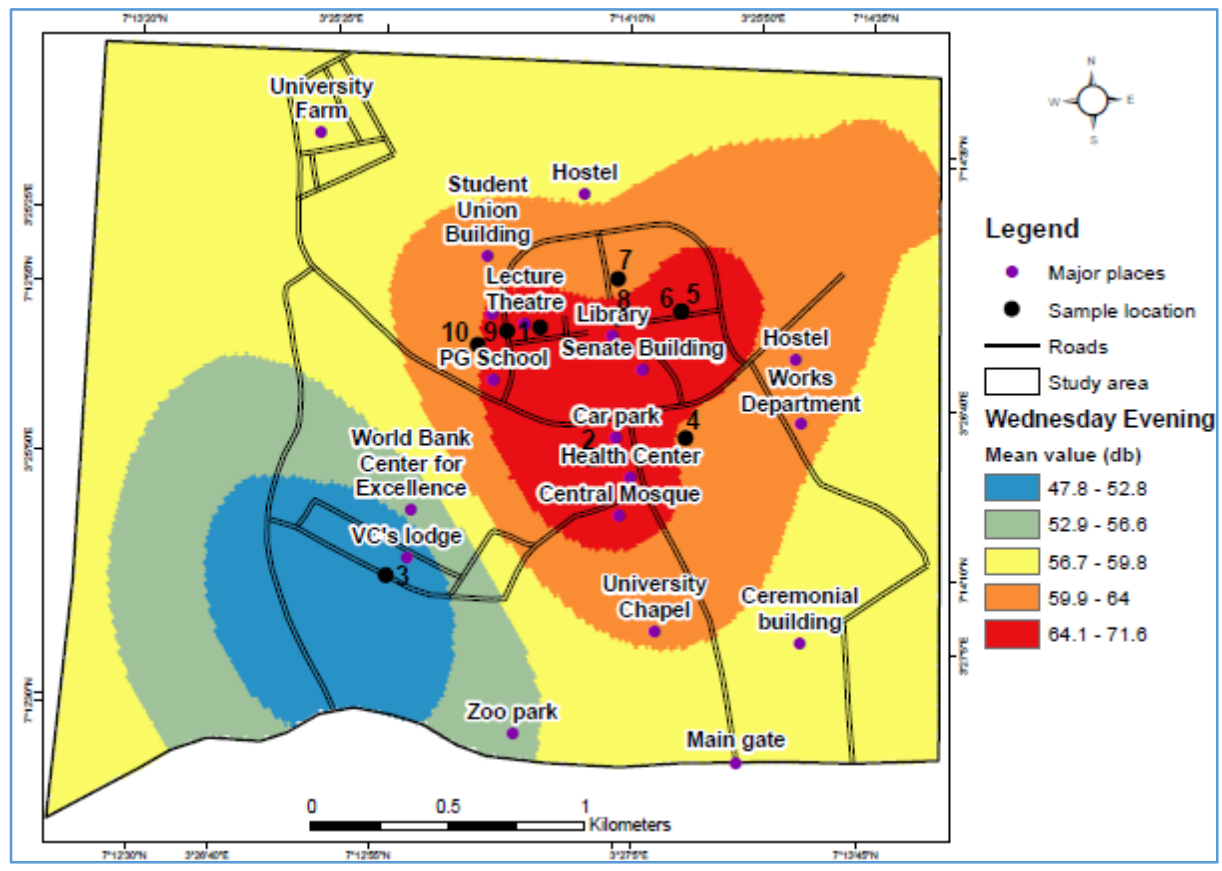

Figure 3b: Spatial variability of average noise level on Wednesday evening

At the Federal University of Agriculture, Abeokuta, Wednesdays are observed as half-day; implying all lectures and academic activities ends by mid-day to allow students relax and socialize. The average value of 72.8 decibels around the car park is not a mere coincidence; the car park is a joint for one of the student's active social groups "Keggites". Here the keggites sing and beat drums from late afternoon till evening. Woolner and Hall (2010) supported the fact that social activities contribute significantly to noise levels in schools. The half-day observed on Wednesdays permit all sorts of social interactions amidst students. This explains the extension of the noisiest zone to the Postgraduate school which has been less noisy on Mondays to the early hours of Wednesdays. Similarly, the slight difference between the noise level at the car park for Mondays and Wednesday can be explained by the activity of one social club; 'Keggites' whose joint is close to the car park.

In Table 6 the noise level on Saturdays are presented. The noise measurements on Saturdays were recorded to have a basis for comparison of weekdays and weekends. Table 6 presents the result for three Saturday mornings and evenings.

Table 6: Saturday morning and evening noise measurement

\begin{tabular}{llllllll}
\hline S/N & Location & Sm1 & Se1 & Sm2 & Se2 & Sm3 & Se3 \\
\hline 1 & SUB & 54.3 & 51.5 & 55.2 & 54.1 & 54.3 & 51.5 \\
2 & CARPARK & 60.5 & 56.7 & 61.7 & 55.5 & 61.2 & 57.8 \\
3 & VCLODGE & 43.7 & 42.1 & 43.2 & 41.1 & 41.0 & 31.1 \\
4 & COLMAS & 35.5 & 33.3 & 35.4 & 31.3 & 30.3 & 59.9 \\
5 & JAO & 71.9 & 59.5 & 70.1 & 58.1 & 69.8 & 53.2 \\
6 & LIBRARY & 49.2 & 51.5 & 49.7 & 54.5 & 50.5 & 61.7 \\
7 & YAT & 56.1 & 65.7 & 57.8 & 68.1 & 58.5 & 61.5 \\
8 & COLERM & 53.6 & 45.5 & 54.7 & 48.1 & 55.1 & 47.6 \\
9 & MP & 49.1 & 45.1 & 50.1 & 46.6 & 51.2 & 45.5 \\
10 & SUB & 45.1 & 42.3 & 48.5 & 45.5 & 49.2 & 43.2 \\
\hline
\end{tabular}

KEYS SM1-Saturday morning week1, SE1-Saturday evening week1,SM2 -Saturday morning week2, SE2 -Saturday evening week2, SM3 -Saturday morning week3,SE3 -Saturday evening week3.

The noise levels were considerably lower than what were recorded during the week days. Seven locations had average noise levels lower than 55 decibels for morning and evenings. The three locations with exceptions are the student hostel (YAT) with morning and evening noise levels of 57.5 and 65.1 respectively. The car park is slightly noisy (with average of $61.1 \mathrm{~dB}$ ) in the morning as many students crowd the park to hop on buses to town. It was surprising that JAO is still noisy (70.6 dB) on Saturday morning although less noisy in its evenings (with average of $56.9 \mathrm{~dB}$ ). This suggests that some lectures still hold these lecture theatres during weekends. JAO's noise level is an indication that the three lecture theatres in that location are the student's favourite reading centre after the library. The hostel noise level is at this level in the morning because of students outing to town on Saturday 
morning and due to power failure which prevents the use of sound systems within the halls. The noise level rises slightly on Saturday evenings as more students returns from town.

Figure 4 provides a clearer picture of the spatial variability of the noise on weekends. The map depicts a more tranquil environment on Saturday morning for most parts of the campus; the noisy areas are localized compared to the other days.

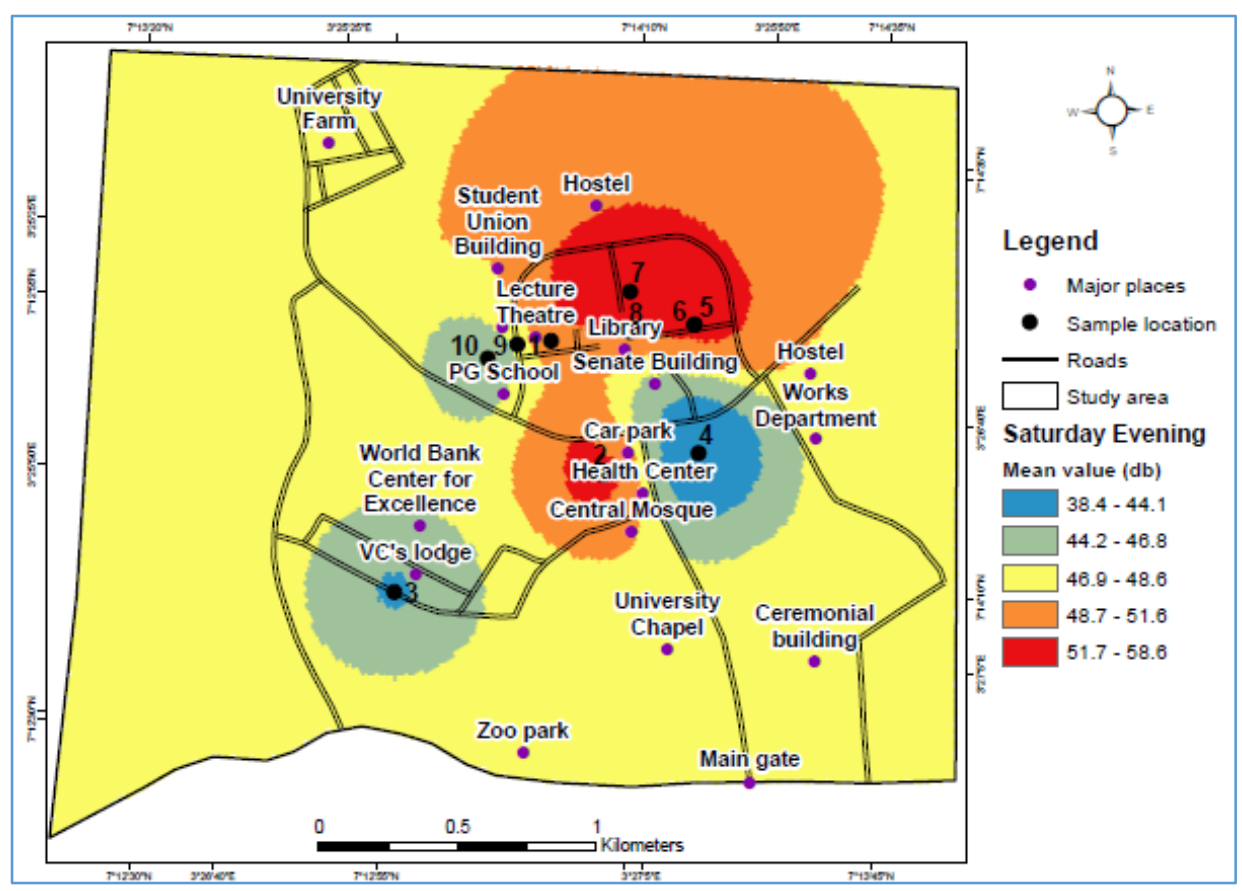

Figure 4a: Spatial variability of average noise level on Saturday morning

The map shows calmness extending to the health and religious centres on Saturdays. The areas depicted as the noisiest equally shrunk in its coverage. The values recorded for the noise levels had also reduced.

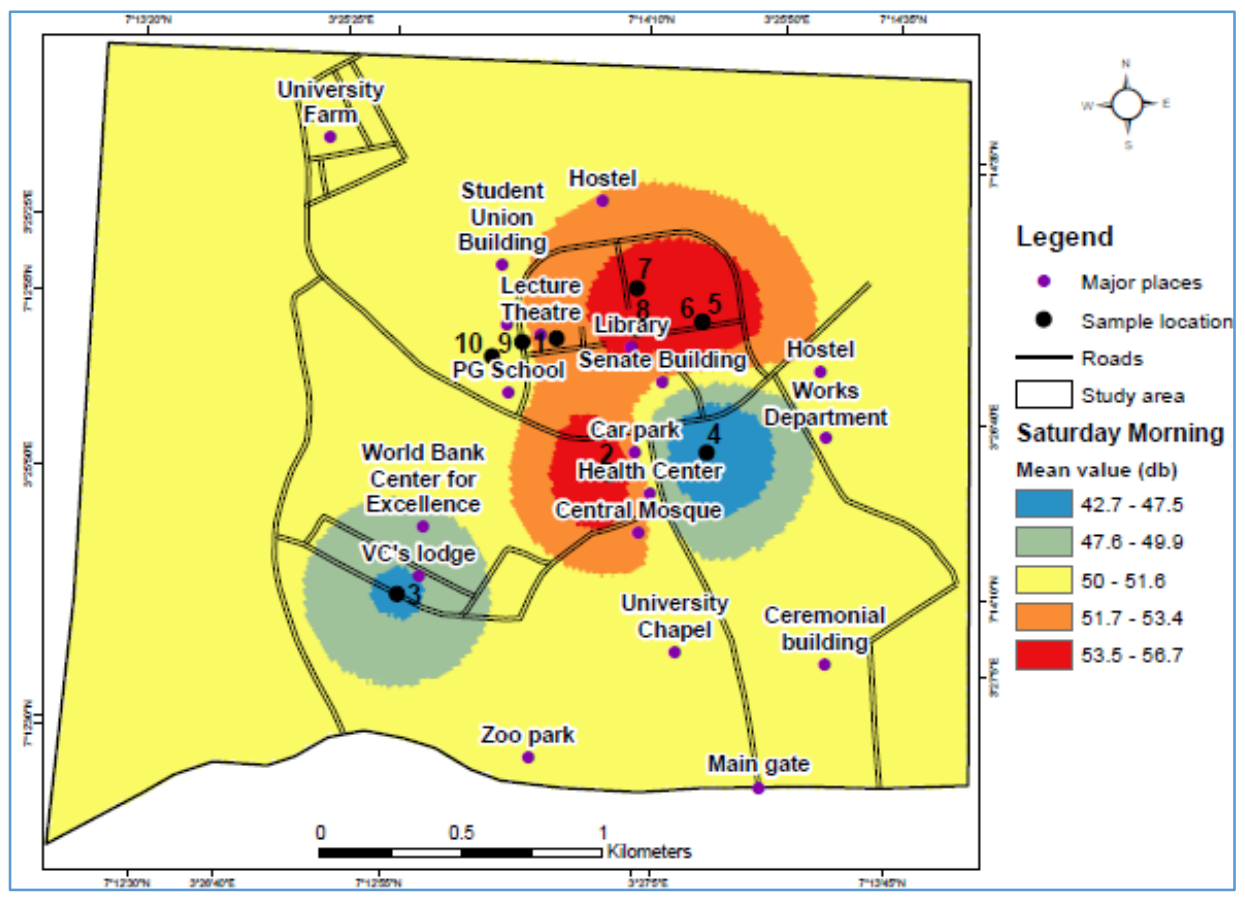

Figure 4b: Spatial variability of average noise level on Saturday Evening

Noise pollution in the campus is not as much as the weekdays; this could be reason why student in town and hostel prefer reading inside campus. Khaiwal et al. (2016) also noted that weekdays are 
noisier than weekends on campuses. This map shows Saturday evening as the most tranquil because the campus is largely non-residential.

\subsection{Spatio-temporal analysis of campus noise pollution}

Table 7 presents the mean values of the noise pollution within the campus in different time, days and locations.

Table 7: Mean $( \pm \mathrm{SD})$ of noise pollution based on days of the week

\begin{tabular}{lllll}
\hline & Monday & Wednesday & Saturday & P-value \\
\hline SUB & $61.10 \pm 5.89^{\mathrm{a}}$ & $62.10 \pm 4.49^{\mathrm{a}}$ & $53.33 \pm 1.42^{\mathrm{b}}$ & 0.01 \\
CAR PARK & $67.67 \pm 3.61^{\mathrm{a}}$ & $67.82 \pm 5.63^{\mathrm{a}}$ & $58.82 \pm 2.48^{\mathrm{b}}$ & 0.00 \\
VC LODGE & $47.75 \pm 1.38^{\mathrm{a}}$ & $46.32 \pm 1.92^{\mathrm{a}}$ & $41.58 \pm 1.15^{\mathrm{b}}$ & 0.00 \\
COLMAS & $63.97 \pm 2.43^{\mathrm{a}}$ & $62.40 \pm 2.00^{\mathrm{a}}$ & $31.97 \pm 2.05^{\mathrm{b}}$ & 0.00 \\
JAO & $72.50 \pm 2.36^{\mathrm{a}}$ & $73.97 \pm 2.64^{\mathrm{a}}$ & $64.83 \pm 6.28^{\mathrm{b}}$ & 0.00 \\
LIBRARY & $61.80 \pm 8.66^{\mathrm{a}}$ & $62.73 \pm 6.43^{\mathrm{a}}$ & $51.57 \pm 1.96^{\mathrm{b}}$ & 0.01 \\
IYAT & $53.93 \pm 3.61^{\mathrm{b}}$ & $57.13 \pm 2.92^{\mathrm{ab}}$ & $61.43 \pm 4.66^{\mathrm{a}}$ & 0.01 \\
COLERM & $65.88 \pm 1.41^{\mathrm{a}}$ & $66.35 \pm 2.17^{\mathrm{a}}$ & $50.83 \pm 4.25^{\mathrm{b}}$ & 0.00 \\
MPB & $61.98 \pm 2.45^{\mathrm{a}}$ & $63.13 \pm 6.55^{\mathrm{a}}$ & $48.12 \pm 2.77^{\mathrm{b}}$ & 0.00 \\
YAKUB & $60.67 \pm 5.50^{\mathrm{a}}$ & $64.65 \pm 2.46^{\mathrm{a}}$ & $45.75 \pm 2.92^{\mathrm{b}}$ & 0.00 \\
\hline
\end{tabular}

Means with different superscripts along same rows are significantly different $(p<0.05)$

On average, the noisiest day in the week was Wednesday. This especially held true at JAO lecture theatre, the car park and COLERM. The trend was however different at the VC's lodge and COLMAS which noisiest day was Monday. Xie (2020) in a noise-related 911 incidents found that there could be significant difference in noise levels of different days of the week. Table 8 is the average noise pollution with respect to period of the day.

Table 8: Mean $( \pm \mathrm{SD})$ of noise pollution based on time of the day

\begin{tabular}{llllll}
\hline & Morning & Evening & T-value & P-value & Remarks \\
\hline SUB & $56.16 \pm 2.08$ & $61.53 \pm 7.04$ & -2.198 & 0.04 & S \\
CARPARK & $62.77 \pm 1.71$ & $66.77 \pm 7.72$ & -1.517 & 0.15 & NS \\
VCLODGE & $44.96 \pm 2.85$ & $45.48 \pm 3.41$ & -0.352 & 0.73 & NS \\
COLMAS & $52.42 \pm 15.44$ & $53.13 \pm 16.08$ & -0.096 & 0.93 & NS \\
JAO & $72.03 \pm 2.29$ & $68.83 \pm 7.59$ & 1.211 & 0.24 & NS \\
LIBRARY & $55.34 \pm 6.37$ & $62.06 \pm 8.17$ & -1.943 & 0.07 & NS \\
IYAT & $54.72 \pm 2.77$ & $60.28 \pm 4.82$ & -2.999 & 0.01 & S \\
COLERM & $62.17 \pm 5.82$ & $59.88 \pm 9.77$ & 0.604 & 0.56 & NS \\
MP & $56.34 \pm 4.54$ & $59.14 \pm 10.73$ & -0.721 & 0.48 & NS \\
YAKUB & $58.62 \pm 8.68$ & $55.42 \pm 9.78$ & 0.734 & 0.47 & NS \\
\hline
\end{tabular}

$S=$ significant $(p<0.05), N S=$ not significant $(p>0.05)$

The variation in noise levels was significantly different through the week with the weekdays being significantly noisier than the weekends at $>99 \%$ confidence level except at the hostels where noise was significantly higher on weekends than on weekdays. Past studies such as (Oyedepo and Saadu, 2008b; Tsai et al., 2009; Oyedepo and Saadu, 2010) agreed with significant differences in noise levels at different periods of the day. The mean difference in intra-day noise levels in Federal University Abeokuta campus were however only significant at the commercial centres (SUB) and hostels (IYAT). They were significant at $\geq 95 \%$ confidence level. A more comprehensive presentation of this phenomenon is presented in Table 9. 
Table 9: Mean $( \pm \mathrm{SD})$ of Noise pollution based on locations

\begin{tabular}{|c|c|c|c|c|c|c|}
\hline & MM & ME & WM & WE & SM & SE \\
\hline SUB & $55.93 \pm 1.76^{\mathrm{ef}}$ & $66.27 \pm 1.91^{\text {bcd }}$ & $58.23 \pm 1.59^{\mathrm{cd}}$ & $65.97 \pm 1.76^{\text {bcd }}$ & $54.30 \pm 0.00^{\mathrm{d}}$ & $52.37 \pm 1.50^{\mathrm{c}}$ \\
\hline CARPARK & $64.47 \pm 1.02^{\mathrm{bc}}$ & $70.87 \pm 0.86^{\mathrm{ab}}$ & $62.87 \pm 1.16^{\mathrm{bc}}$ & $72.77 \pm 2.08^{\mathrm{ab}}$ & $60.97 \pm 0.40^{b}$ & $56.67 \pm 1.15^{b}$ \\
\hline VCLODGE & $47.07 \pm 1.79^{g}$ & $48.43 \pm 0.40^{g}$ & $45.90 \pm 2.21^{\mathrm{e}}$ & $46.73 \pm 1.94^{\mathrm{e}}$ & $41.90 \pm 1.56^{\mathrm{f}}$ & $41.27 \pm 0.76^{\mathrm{f}}$ \\
\hline COLMAS & $62.53 \pm 2.84^{\mathrm{bcd}}$ & $65.40 \pm 0.75^{\mathrm{cd}}$ & $62.70 \pm 0.72^{\mathrm{bc}}$ & $62.10 \pm 3.04^{\mathrm{cd}}$ & $32.03 \pm 3.00^{\mathrm{g}}$ & $31.90 \pm 1.22^{\mathrm{g}}$ \\
\hline JAO & $71.93 \pm 3.44^{\mathrm{a}}$ & $73.07 \pm 1.08^{a}$ & $73.67 \pm 0.45^{\mathrm{a}}$ & $74.27 \pm 4.11^{\mathrm{a}}$ & $70.50 \pm 1.21^{\mathrm{a}}$ & $59.17 \pm 0.95^{b}$ \\
\hline LIBRARY & $54.00 \pm 2.26^{\mathrm{f}}$ & $69.60 \pm 0.10^{\mathrm{abc}}$ & $61.97 \pm 6.82^{b c}$ & $63.50 \pm 7.43^{\mathrm{cd}}$ & $50.07 \pm 0.75^{\mathrm{e}}$ & $53.07 \pm 1.50^{c}$ \\
\hline YAT & $51.80 \pm 1.57^{\mathrm{f}}$ & $56.07 \pm 4.05^{\mathrm{f}}$ & $54.67 \pm 0.35^{\mathrm{d}}$ & $59.60 \pm 1.71^{\mathrm{d}}$ & $57.70 \pm 1.39^{c}$ & $65.17 \pm 3.23^{\mathrm{a}}$ \\
\hline COLERM & $66.60 \pm 0.46^{\mathrm{b}}$ & $65.17 \pm 1.80^{\mathrm{cd}}$ & $65.30 \pm 2.15^{b}$ & $67.40 \pm 1.95^{\mathrm{abc}}$ & $54.60 \pm 0.87^{\mathrm{d}}$ & $47.07 \pm 1.38^{\mathrm{d}}$ \\
\hline MP & $59.93 \pm 1.42^{\mathrm{de}}$ & $64.03 \pm 0.61 \mathrm{de}$ & $58.60 \pm 0.95^{\mathrm{cd}}$ & $67.67 \pm 6.69^{a b c}$ & $50.50 \pm 1.21^{\mathrm{e}}$ & $45.73 \pm 0.78^{\mathrm{de}}$ \\
\hline YAKUB & $61.97 \pm 4.62^{\mathrm{cd}}$ & $59.37 \pm 7.01^{\text {ef }}$ & $66.07 \pm 0.47^{b}$ & $63.23 \pm 2.98^{\mathrm{cd}}$ & $47.83 \pm 2.37^{\mathrm{e}}$ & $43.67 \pm 1.65^{\mathrm{ef}}$ \\
\hline
\end{tabular}

In terms of time of day, the mean noise levels were higher in the evening than in the mornings except at the lecture theatres.

\subsection{Sources of the noise pollution and its consequences on productivity of staff and students}

The assessment of the sources of noise showed the most important noise origins to be electrical generators especially beside the library and JAO which automatically affect COLANIM Building, social interaction and social events respectively. As can also be seen from the table above, academic interaction constitutes the barest minimum of the noise present within the study area.

The major consequence of noise within the study area is the prevention of effective reading. Approximately, $60 \%$ of all respondents encountered within the study area noted this as a major consequence of noise within the school environment. The opinion of staff and student respondents is presented in the Table 10 .

Table 10: Consequences of noise pollution on productivity of staff and student

\begin{tabular}{lll}
\hline Noise effects & $\%$ agreement & $\%$ disagreement \\
\hline Prevents effective reading/assimilation & 60 & 40 \\
Prevents effective communication & 47 & 53 \\
Causes distractions/diversions & 27 & 73 \\
Breaks concentration & 40 & 60 \\
Reduced Overall Academic Input/output & 47 & 53 \\
\hline
\end{tabular}

$60 \%$ of the respondents agreed perfectly that noise in FUNAAB hinders effective understanding during reading. Most people however disagreed that it hinders effective communications, or causes poor performance. About $73 \%$ even opined that noise does not cause distractions. Only $47 \%$ believe that noise can over all academic output. These responses indicate that people have adjusted to a lifestyle that copes with environmental noise.

\subsection{Conclusion}

From this research, the following conclusions have been drawn;

1. Noise levels are higher during the week in the school except at the hostels and commercial centers within the school environs.

2. The noise levels are higher in the evening than in the mornings except at the lecture theatres.

3. The sources of noise showed the most important noise origins to be electrical generators, social interaction and social events.

4. The major consequence of noise within the study area is the prevention of effective reading.

5. Other discovered effects included the prevention of effective communication, reduction of overall academic input/output, disruption of concentration and prevention of effective dissimulation (staff) and assimilation (student). 
6. According to the World Health Organization, the permissible noise level in school environment should not exceed $35 \mathrm{db}$ the sound pressure level of the noise from external sources should not exceed $55 \mathrm{db}$ laeq (Berglund et al., 2000). The same value given for outdoor residential areas in day-time. This shows that noise level within FUNAAB Campus is very high.

7. Noise level is higher in the library due to the use of diesel generator.

Recommendations:

1. This research recommends that a conscious effort should be made to reduce noise levels by addressing the causes of said noise. This can be addressed by implementing a central energy generation plan to reduce the use of generator sets especially at the school library.

2. The creation of recreation and socialization centers should be made away from both active and passive study centers to reduce destructive interaction between people involved in academic and social activities

3. Proper enforcement of already existing legislation to control noise pollution should be implemented.

\section{References}

Abulude, F.O., Fagbayide, S.D., Olubayode, S.A. and Adeoya, E.A. (2018). Assessment of noise pollution due to generators in Akure, Ondo State, Nigeria. Environmental Research \& Technology, $1(3)$, pp. 59-62.

Akintunde, E. A., Bayei, J. Y., and Akintunde, J. A. (2020). Noise level mapping in University of Jos, Nigeria. GeoJournal. doi:10.1007/s10708-019-10135-w

Alsubaie, A. S. R., (2014). Indoor noise pollution in elementary schools of eastern province, Saudi Arabia. Journal of Research in Environmental Science and Toxicology, 3(2), pp.25 - 29

Ana, G.R.E.E., Shendell, D.G., Brown, G.E. and Sridhar, M.K.C., (2009). Assessment of noise and associated health impacts at selected secondary schools in Ibadan, Nigeria. Journal of Environmental and Public Health, pp.1-6

Annick, G., Dirk, D., Guido, V., Kristien, W., Andrea, P.K. and Paul, V. (2012). Prevalence of Leisure Noise-Induced Tinnitus and the Attitude Toward Noise in University Students. Otology \& Neurotology, 33 (6), pp.899-906 doi: 10.1097/MAO.0b013e31825d640a

Augustyńska, D., Kaczmarska, A., Mikulski, W. and Radosz, J., (2010). Assessment of Teachers' Exposure to Noise in Selected Primary Schools. Archives of Acoustics, 35 (4), pp.521-542

Aweda, M. A., Usikalu, M. R., Ding, N., Wan, J. H. and Zhu, J. (2010) Genetoxic effects of 2.45 $\mathrm{GHz}$ microwave exposure on different cells of Sprague Dawley rats. International Journal Genetics and Molecular Biology, 2(9), pp. 189-197.

Bakasa, L., (2011). Effect of class size on academic achievement at a selected institution of higher learning, University of South Africa, Pretoria. A master of education thesis in didactics at the University of South Africa 148pg. http://hdl.handle.net/10500/5759

Baloye., D.O.; Palamuleni, L.G. (2015). A Comparative Land Use-Based Analysis of Noise Pollution Levels in Selected Urban Centers of Nigeria. Int. J. Environ. Res. Public Health, 12, pp. 1222512246.

Basner, M., Babisch, W., Davis, A., Brink, M., Clark, C. et al., (2014). Auditory and non-auditory effects of noise on health. 383(9925), pp.1325-1332 
Berglund, B., Lindvall, T., \& Schwela, D. H. (2000). New Who Guidelines for Community Noise. Noise \& Vibration Worldwide, 31(4), pp. 24-29 https://doi.org/10.1260/0957456001497535

Buxton, R. T., McKenna, M. F., Mennitt, D., Fristrup, K., Crooks, K., Angeloni, L., and Wittemyer, G. (2017). Noise pollution is pervasive in U.S. protected areas. Science, 356 (6337), pp. 531-533 DOI: $10.1126 /$ science.aah4783

Debnath, D., Nath, S. K. and Barthakur, N. K. (2012). Environmental noise pollution in educational institutes of Nagaon town, Assam, India. Global Journal of Science Frontier Research Environment and Earth Sciences, 12(1), pp.1-5

Digha, O.N. and Tabe, A.E. (2013). Assessment of Noise Pollution Level In Trans-Amadi Industrial Lay-Out In Port Harcourt Rivers State, Nigeria. Journal of Environmental Sciences and Resources Management, 5(1), pp. 65-73.

Dockrell J.E., and Shield B., (2012). The impact of sound-field systems on learning and attention in elementary school classrooms J. Speech Lang Hear Res 55(4), pp.1163-76

Elmenhorst, E., Elmenhorst, D., Wenzel, J., Quehl, J., Mueller, U., et al., (2010). Effects of nocturnal aircraft noise on cognitive performance in the following morning: dose-response relationships in laboratory and field. Int Arch Occup Environ Health, 83, pp.743-751 https://doi.org/10.1007/s00420010-0515-5

Emenike, G. C. and Sampson, A. P. (2017). Noise levels and quality of livelihoods in residential Neighbourhoods of Port Harcourt metropolis, Nigeria. European Journal of Earth and Environment, 4 (1), pp. 19-28. Progressive Academic Publishing, UK Page 19 www.idpublications.org

Essandoh, P. K., and F. A. Armah. (2011). Determination of Ambient Noise levels in the main commercial area of Cape Coast, Ghana. Research Journal of Environmental and Earth Sciences, 3(6), pp.637-44

Feng, H. and Li, J. (2016). Head teachers, peer effects, and student achievement. Han Feng and Jiayao Li. China Economic Review, 41, (C), pp. 268-283.

Gilavand, A. And Jamshidnezhad, A. (2016). The effects of noise in educational institutions on learning and academic achievement of elementary students in Ahvaz, South West of Iran. International Journal of Pediatrics, 4(3), pp.1453-1463

Golmohammadi, R., Ghorbani, F., Mahjub, H. and Daneshmeh, Z., (2010). Study of school noise in the capital city of Tehran-Iran. Iran Journal of Environmental Health, Science and Engineering, 7(4), pp.365-370

Gupta, A., Gupta, A., Jain, K. and Gupta, S. (2018). Noise Pollution and Impact on Children Health. Indian J Pediatr, 85, pp. 300-306 https://doi.org/10.1007/s12098-017-2579-7

Hagen, M., Huber, L. And Kahlert, J. (2002). Acoustic school design. Forum Acusticum Sevilla. Pp. $1-7$.

Hygge, S., Evans, G. W., and Bullinger, M., (2002). A Prospective Study of Some Effects of Aircraft Noise on Cognitive Performance in Schoolchildren. Psychological Science, 13(5), pp. 469-474. Doi:10.1111/1467-9280.00483

Ikenberrgy, L. D. (1974). School noise and its control. Journal of Environmental Health, 36(5), pp. 493-499.

Kamal, M., El-Rahman, R.A. and Tawfiq, S. (2010). Evaluation of Noise Levels affecting Schools in Cairo-Egypt. In: Proceedings of ISMA2010 including USD2010, pp.1811-1820 
Karamikh, C. M, and Firoozabadi M., (2012). Traffic Noise as a series effect on class teachers in Firoozabad city. Iran Medical Journal of Islamic World Academy of Sciences, 20(2), pp.48-55

Khaiwal, R., Tanbir Singh, T., Tripathy, J.P., Mor, S., Munjal, S., Patro, B and Panda, N. (2016). Assessment of noise pollution in and around a sensitive zone in North India and its non-auditory impacts. Science of The Total Environment, 566-567, pp. 981-987

Klatte, M., Bergstrom, K. and Lachmann, T., (2013). Does noise affect learning? A short review on noise effects on cognitive performance in children. Frontiers in Psychology, 4, (578), pp.1-6.

Kruger, E.L, and Zannin, P.H.T., (2004). Acoustic, thermal and luminous comfort in classrooms Build. Environ, 39, pp.1055-1063

Lewinski, P. (2015). Effects of classrooms' architecture on academic performance in view of telic versus paratelic motivation: a review. Front Psychol, 6, 746

Lundquist P, Holmberg K, Landstrom U., (2000). Annoyance and effects on work from environmental noise at school. Noise Health, 2, pp.39-46

Mackenzie, D. J., and Galbrun, L. (2007). Noise levels and noise sources in acute care hospital wards. Building Services Engineering Research and Technology, 28(2), pp.117-131 https://doi.org/10.1177/0143624406074468

Marius A., Tijunelis M.D., Fitzsullivan B.A., Sean O. and Henderson M.D. (2005). Noise in the ED. Am. J. Emerg. Med. 23(3), pp. 332-335

Nassiri, P., Monazam, M., Dehaghi, B.F., Abadi, L.I.G., Zakerian, S.A. and Azam, K., (2013). The Effect of Noise on Human Performance: A Clinical Trial. Int. J. of Occup and Environmental Medicine, 4(2), pp.87-95

Nazir, M. S., Ali, N., Bilal, M., and Iqbal, H. M. N. (2020). Potential environmental impacts of wind energy development - A global perspective. Current Opinion in Environmental Science \& Health, doi:10.1016/j.coesh.2020.01.002

Olaosebilan, A. (2020): Effect of noise level on assimilation rate among school children. figshare. Journal contribution. Available at: https://doi.org/10.6084/m9.figshare.12200552.v1

Otutu, O.J. (2011). Investigation of environmental noise within campus, Delta State University, Abraka, Nigeria. IJRRAS, 6 (2), pp. 223-229

Owen, D. (2019). Is Noise Pollution the Next Big Public-Health Crisis? The NewYorker. Dept. of Public Health. Magazine May 13, 2019 Issue. https://www.newyorker.com/magazine/2019/05/13/isnoise-pollution-the-next-big-public-health-crisis

Oyedepo S. O. and Saadu A. A. (2008a). A Statistical Analysis of the Day-time and Night-time Noise Levels in Ilorin Metropolis, Nigeria. Trends in Applied Sciences Research, 3: 253-266. DOI: 10.3923/tasr.2008.253.266

Oyedepo, O. S., and Saadu, A. A. (2008b). A comparative study of noise pollution levels in some selected areas in Ilorin Metropolis, Nigeria. Environmental Monitoring and Assessment, 158(1-4), pp. 155-167. doi:10.1007/s10661-008-0570-5

Oyedepo, O.S., Saadu, A.A. (2010). Evaluation and analysis of noise levels in Ilorin metropolis, Nigeria. Environ Monit Assess, 160, 563 https://doi.org/10.1007/s10661-008-0719-2

Oyedepo, S. O. (2013a) Development of noise map for Ilorin metropolis, Nigeria. International Journal of Environmental Studies, 70 (4), pp. 503-514, DOI: 10.1080/00207233.2013.813716 
Oyedepo, S. O. (2013b). Effective Noise Control Measures and Sustainable Development in Nigeria. World Journal of Environmental Engineering, 1(1), pp. 5-15 DOI:10.12691/wjee-1-1-2 Available online at http://pubs.sciepub.com/wjee/1/1/2

Oyedepo, S.O. Adeyemi, G.A. Fayomi, O.S.I. Fagbemi, O.K. Solomon, R., et al., (2018). Dataset on noise level measurement in Ota metropolis, Nigeria, data in brief, https://doi.org/10.1016/j.dib..12.049

Oyedepo, S.O., Adeyemi, G.A., Olawole, O.C., Ohijeagbon, O.I., Fagbemi, O.K., et al., (2019). A GIS - based method for assessment and mapping of noise pollution in Ota metropolis, Nigeria. MethodsX, 6, pp. 447-457

Passchier-Vermeer, W., and Passchier, W. F. (2000). Noise exposure and public health. Environmental health perspectives, 108, (Suppl 1), pp. 123-131. https://doi.org/10.1289/ehp.00108s1123

Pheng, H.S., Yean, T.S., Lye, K.H., Ismail, A.I.M. and Kassim, S. (2006) Modeling noise levels in USM penang campus. In Proceedings 2nd IMT-GT regional conference on mathematics, statistics \& applications. University Sains Malaysia, Penang.

Piličić, S., Traven, L., Milošević, T., Kegalj, I. i Skoblar, A. (2020). Noise Pollution-Introduction to the State of the Research and the Implementation in the Horizon 2020 Project Pixel . Pomorski zbornik, Special edition (3), pp. 133-145. Preuzeto s https://hrcak.srce.hr/238817

Savale, P. A. (2014). Effects of noise pollution on human being: Its prevention and control. Journal of Environmental Research and Development, 8(4), pp. 1026-1036.

Shendell D. G., Lee, S. M. and Apte, M. G. (2002). Assessment ofnoise exposures in new relocatable classrooms with standard and advanced HVAC systems. In: Proceedings of the 12thAnnual Meeting of the International Society of Exposure Analysis jointly with the 14th International Society of Environmental Epidemiology, Vancouver, Canada, August 2002, abstract in Epidemiology,13, (4), pp. S223.

Simões-Zenari, M., Bitar, M.L. and Nemr, N.K., (2009). The effect of noise on the voice of preschool institution educators. pp7. Research presented at the 17th Brazilian Congress of Speech-Language Pathology and Audiology, held in Salvador (Northeastern Brazil) in 2009

Spreng, M. (2000). Central nervous system activation by Noise. Noise and Health, 2(7), pp.49-57.

Stansfeld, S. A., Haines, M. and Brown, B. (2000). Noise and Health in the Urban Environment. Reviews on environmental health 15(1-2), pp. 43-82 DOI: 10.1515/REVEH.2000.15.1-2.43

Thakur, G.S. (2006). A study of noise around an educational institutional area. Journal of Environmental Science \& Engineering, 48(1), pp.35-38

Tobías, A., Recio, A., Díaz, J. And Linares, C. (2015). Health impact assessment of traffic noise in Madrid (Spain) Environmental Research, 137, pp.136-140

Tsai, K., Lin, M. and Chen, Y. (2009). Noise mapping in urban environments: A Taiwan study. Applied Acoustics, 70 (7), pp. 964-972 doi.org/10.1016/j.apacoust.2008.11.001

Usikalu, M. R., Aweda, M. A., Alimba, C. G. and Achuka, J. A. (2016a). Chromosomal Aberration in Bone Marrow of Sprague Dawley Rats after Exposure to $2.45 \mathrm{GHz}$ Microwave Radiation, Research Journal of Applied Sciences, 11(5), pp. 32-234.

Woolner, P. and Hall, E. (2010) Noise in Schools: A Holistic Approach to the Issue. Int. J. Environ Res Public Health. Aug, 7(8), pp. 3255-3269. doi: 10.3390/ijerph7083255

World Health Organization (2000): Guidelines for Community Noise, World Health Organisation, Geneva 2000 
World Health Organization (2009). Night noise guidelines for Europe. World Health Organization Europe, Copenhagen

Xie, D. (2020) Noise-related 911 incident report for UW students seeking off-campus housing. Available online at: https://public.tableau.com/profile/davidxie\#!/vizhome/Noiserelated911incidentreportforUWstudentsseekingoff-campushousing/Noise-

related911incidentreportforUWstudentsseekingoff-campushousing. Accessed 21st September, 2020.

Zannin, P.H.T., Dini, F.B., Calixto, A. and Barbos, W., (2002). Environmental noise pollution in the city of Curitiba, Brazil. Applied Acoustics, 63(4), pp.351-358.

Zannin, P. H. T. and Zwirtes, D. P. Z. (2009). Evaluation of the acoustics performance of classrooms in public schools. Applied Acoustics, 70, pp.626-635

Zannin, P. H. T., Engel, M. S., Fiedler, P. E. K., \& Bunn, F. (2013). Characterization of environmental noise based on noise measurements, noise mapping and interviews: A case study at a university campus in Brazil. Cities, 31, pp. 317-327. doi:10.1016/j.cities.2012.09.008

\section{Cite this article as:}

Oyedepo J. A., Omoniyi D. M., Oluyege D. E. and Babajide E. I., 2020. Spatial characterization of noise levels at the Federal University of Agriculture, Abeokuta, Nigeria. Nigerian Journal of Environmental Sciences and Technology, 4(2), pp. 324-340. https://doi.org/10.36263/nijest.2020.02.0218 